J. Asiat. Soc. Bangladesh, Sci. 44(2): 127-136, December 2018

\title{
MIGRANT COMMUNITY OF NIJHUM DWIP: COMPARATIVE IMPORTANCE OF LIVELIHOOD CAPITALS TO ADAPT IN THIS ISLAND
}

\author{
AMIT KUMAR AND SABNAM SARMIN LUNA* \\ Department of Geography and Environment, Jagannath University, \\ Dhaka-1100, Bangladesh
}

\begin{abstract}
The study attempts to explore the factors behind selecting Nijhum Dwip for migration and perceive the relative importance of livelihood capitals (Human, physical, natural, financial and social) for the climate change adaptation of migrant community. Both qualitative and quantitative approaches are followed in this study. Data are collected from primary and secondary sources. The study recognizes, people are moving to Nijhum Dwip rather shifting to main land despite facing numerous disasters like cyclone, river bank erosion, flood, storm surge, sea level rise, salinity intrusion and so on. This is mainly due to low price of land and no alternative place to shift. They consider physical capital as the strongest livelihood capital to adapt in this island followed by human capital, natural capital, financial capital as well as social capital are also suitable option for enhancing the adaptation of migrant community to settle there.
\end{abstract}

Key words: Migrant community, Adaptation, Livelihood capital, Climate change, Nijhum Dwip

\section{Introduction}

Migration is one of the most important survival strategies adopted by people in the face of natural or man-made disasters (IOM 2008, Siddiqui 2014). A number of factors influence people to migrate, often with a combination of forced and voluntary reasons combining to push them away from current situations and to pull them towards new situations. Climate change is one of the main reasons for migration (Stojanov et al. 2016). This is likely to contribute displacement and increase both internal and international migration, with current projections estimating that by 2050, 200 million people will become displaced due to environmental factors (Pascoe 2015). Climatic events can affect migration in numerous ways: it might be temporary or permanent, planned or spontaneous, within states or across national borders and can involve individuals, households or communities (Pascoe 2015). Coastal areas are one of the most vulnerable spaces because of sea-level rise, increased level of inundation and

*Author for correspondence: E-mail: sarminluna@yahoo.com 
storm flooding, coastal erosion, seawater intrusion and increased temperature (Torresan et al. 2008). However, a great change has been observed in the pattern of migration in Bangladesh especially in the off-shore islands of coastal areas due to the intensification of natural hazards. In the context of Bangladesh, natural disasters play considerable role in forcing people to migrate as a coping strategy (Rayhan and Grote 2007, Siddiqui 2014). Here, the most critical impact of climate change will result in the migration of the people from coastal areas to all over the country (Barman et al. 2012). There are major islands in coastal area of Bangladesh like Bhola, Sandwip, Hatia, Kutubdia, Moheshkhali, Saint Martin becoming vulnerable due to climate change (Tanim and Roy 2013). Nevertheless, these people do not migrate to mainland rather they migrate to intra-island among same Upazila or district. Because the new born islands facilitates several pull factors for the poor migrants such as, low land price, high fertility and productivity of agriculture lands, massive amount of unclaimed natural resources like timber or fisheries etc., sometimes incentives from the local government authorities and so forth. It is found from the studies that large number of migrants are shifting to Nijhum Dwip in spite of facing natural calamity like cyclone, river bank erosion, flood, storm surge, sea level rise, salinity intrusion etc. The migrants create many ways for living in this island and they are adapting with climate change induced hazards (flood, river bank erosion, storm surge, cyclone and sea level rise). This vulnerable people may be getting scope for living in this island for having livelihood assets (Physical, natural, human, financial and social).

A study on fishing community used livelihood assets for analyzing their resilience in Nijhum Dwip. The study depicted that natural asset is the most significant for fishermen resilience. The effectiveness of human, financial and social assets are moderately significant, where the physical asset is the least significant in fishermen resilience (Hossain et al. 2013). Warrick also added that people of Pacific islands inhabit in coastal areas due to the availability of natural resources for their livelihood and wellbeing ( Campbell and Warrick 2014).

A very few studies have been done on migrant community of Nijhum Dwip and livelihood capital has hardly been exercised to perceive the adaptation of migrant community in this island. The study findings can improve our understanding of the issue of internal displacement in the country and might also add value to the existing knowledge products on climate change and disaster. This study can be an important document for policy makers, planners and government officials to take appropriate decision whether to relocate the vulnerable population to new places or retain them in their ancestral home through enhancing their resilience. 
The specific objectives of the study are to find out the factors behind selecting Nijhum Dwip for migration and to identify the relatively prominent livelihood capitals to adapt in the island.

The present study was carried out on the migrant community of Nijhum Dwip island under Hatiya Upazila of Noakhali district in Bangladesh. It is Southern most island of Bangladesh that confluences of Meghna estuary of Bengal (South and West), the island is about 2.2 meters high from the sea level (Saha et al. 2014). Coastal area is very dynamic in nature. Nijhum Dwip is one of the timeworn islands where erosion and accretion simultaneously happen like other islands situated in the Meghna estuary. According to the satellite imagery the mudflat land is the most unstable and usually its movement is unpredictable. Data found from a study done by Hossain et al. (2016) the mangrove forest is decreasing while the homestead forest and cultivable lands are increasing which indicates that population settlement of Nijhum Dwip is growing over the year. Population of Nijhum Dwip increased to 12796 from 7835 in one decade commencing from 2001 (BBS 2011).

\section{Materials and Methods}

The study was conducted based on both primary and secondary data. Secondary data were collected from various published and unpublished sources for instance, journal, book, thesis paper and so on while interviews with migrant families using semi-structured questionnaires constitute the major source of empirical data. Information was collected from the household head. The total number of households in Nijhum Dwip are 2464 (BBS 2011). Maximum people live in the southern part of Nijhum Dwip. There is no available statistics how many families migrated to Nijhum Dwip. That is why 50 migrant families were taken from the southern part of Nijhum Dwip by using snowball sampling technique in order to know why they migrated to this island instead of main land and which assets helped them keep staying there. The families, migrated to this island at least before one year were selected for the survey. Livelihood capitals (Physical, natural, human, financial and social) from sustainable livelihood approach (SLA) provided by DFID (1999) has been taken to identify the comparative importance of these capitals in the form of adaptation in this island. The five components for each capital are decided by the author in order to fulfill the objectives. After having the collected data from the field, the surveyed information was examined and processed by using computer software SPSS (Spatial package for social science) while ArcGIS10.3.1 was used to produce the map of migrant's source to Nijhum Dwip and MS Excel was also used for making charts and diagrams. In addition, Adobe Photoshop and Illustrator software were used for preparing 
pentagons of livelihood capitals. The relative importance scale (Table 1) was used in order to determine the priority for each criterion of livelihood capitals among migrant's community. The comparative significance of various indicators of capitals was calculated by the given value of the scale. No negative reply was given by the respondents regarding the importance of livelihood capitals. The total value of each criterion multiplied with the scale value and then divided by total number 50 and this result was shown in each pentagon of capitals. Thus from the average value of five capitals, final livelihood pentagon was produced.

Table 1. The relative importance of criteria (Assumed value by author).

\begin{tabular}{lcccccccc}
\hline Extreme & $\begin{array}{c}\text { Very } \\
\text { strong }\end{array}$ & Strong & Moderate & Neutral & Moderate & Strong & $\begin{array}{c}\text { Very } \\
\text { strong }\end{array}$ & Extreme \\
\hline $1 / 5$ & $1 / 4$ & $1 / 3$ & $1 / 2$ & 1 & 2 & 3 & 4 & 5 \\
& Less importance & & & & More importance \\
\hline
\end{tabular}

\section{Results and Discussion}

Overall, there are many reasons why people migrate, where contemporary climatic events suggested as a key force towards more migration. The study also recognizes the same, explaining various losses of migrant's family due to natural disasters before their migration to Nijhum Dwip, which disaster mainly forced them to migrate, why they prefer Nijhum Dwip to settle there and from where they arrived in the island for living.

Losses of migrant families due to natural disasters before migration to Nijhum Dwip: People living in coastal and offshore islands of Bangladesh have been facing a problem of losing their homes and sources of livelihoods by natural hazards and are forced to move further into the sea (Siddiqui 2014). The Table 2 shows that before their migration, the migrant families were greatly affected by catastrophic disaster causes loss of homestead, infrastructure, agriculture land, crops, livestock, and employment which actually forced them away to Nijhum Dwip. As per study, cent per cent of the families lost their homestead and agriculture land, 96\% families lost their crops, 92\% hampered infrastructure and livestock for each and 30\% lost their employment due to disaster.

Influential climatic events behind migration to Nijhum Dwip: In 1990, the Intergovernmental Panel on Climate Change (IPCC) noted that the greatest single impact of climate change could be on human migration with millions of people displaced by shoreline erosion, coastal flooding and agricultural disruption (Brown 2008). Extreme climate events like floods, cyclones and tidal surges, as well as gradual impacts of 
climate change like salinity or river erosion cause climate induced migration (Anwer 2012). The findings of the study show that most of the families (84\%) displaced to Nijhum Dwip due to river bank erosion and $10 \%$ families migrated due to cyclone and only $6 \%$ families shifted because of flood disaster (Table 3 ).

Table 2. Losses of migrant families due to natural disasters before migration to Nijhum Dwip.

\begin{tabular}{lclc}
\hline Losses & $\mathrm{N}=50(\%)$ & Losses & $\mathrm{N}=50(\%)$ \\
\hline Homestead loss & $50(100)$ & Crops Loss & $48(96)$ \\
Infrastructure loss & $46(92)$ & Livestock Loss & $46(92)$ \\
Agriculture land loss & $50(100)$ & Employment Loss & $15(30)$ \\
\hline
\end{tabular}

Source: Field survey, 2017 parenthesis shows the percentage.

Table 3. Influential climatic events behind migration to Nijhum Dwip.

\begin{tabular}{lc}
\hline Name of disaster & Percentage \\
\hline River bank erosion & 84 \\
Flood & 10 \\
Cyclone & 6 \\
Total & 100 \\
\hline
\end{tabular}

Source: Field survey, 2017.

Reasons for selecting Nijhum Dwip for migration: The study reveals that most of the families (86\%) migrated to Nijhum Dwip considering the low price of land, $82 \%$ families shifted because they have no alternative place to go, $72 \%$ mentioned the area is easy to migrate and the other motives to move this island were followed by near to house (48\%), available facilities (46\%), save zone from before (40\%), rearing up cattle (38\%) and very few of them recognized that they can reside together (16\%) and only $2 \%$ of them said the area is above from flood level (Fig. 1).

Source of migration: The Map 1 demonstrates the origin place of migrant families. It is evident that the migrants were mainly from the neighbouring area of Nijhum Dwip specially from the different unions of Hatiya Upazila, but they came from northern part of Hatiya upazila to Southern most part of the Upazila called Nijhum Dwip which is towards the sea. Most of the respondents (37\%) migrated from Jahajmara union, about $22 \%$ from Sukh char, $13 \%$ from Charking, 9.3\% from Nalsira, $7.4 \%$ from Burir char, $5.6 \%$ from Sonadia union and followed by approximately 4 and $2 \%$ migrated from Tomuriddin and Char Ishwar, respectively. 


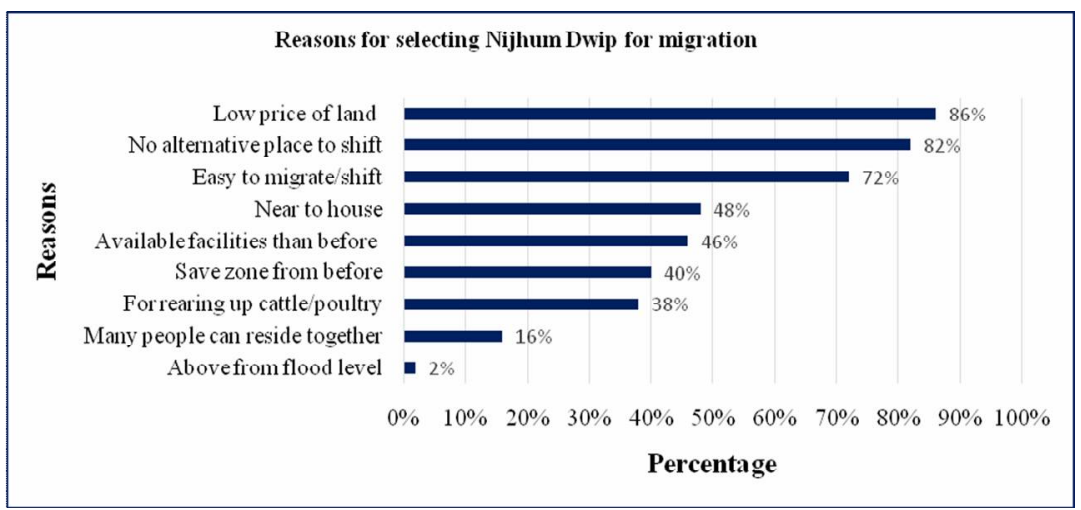

Source: Field survey, 2017

Fig. 1. Reasons for selecting Nijhum Dwip for migration.

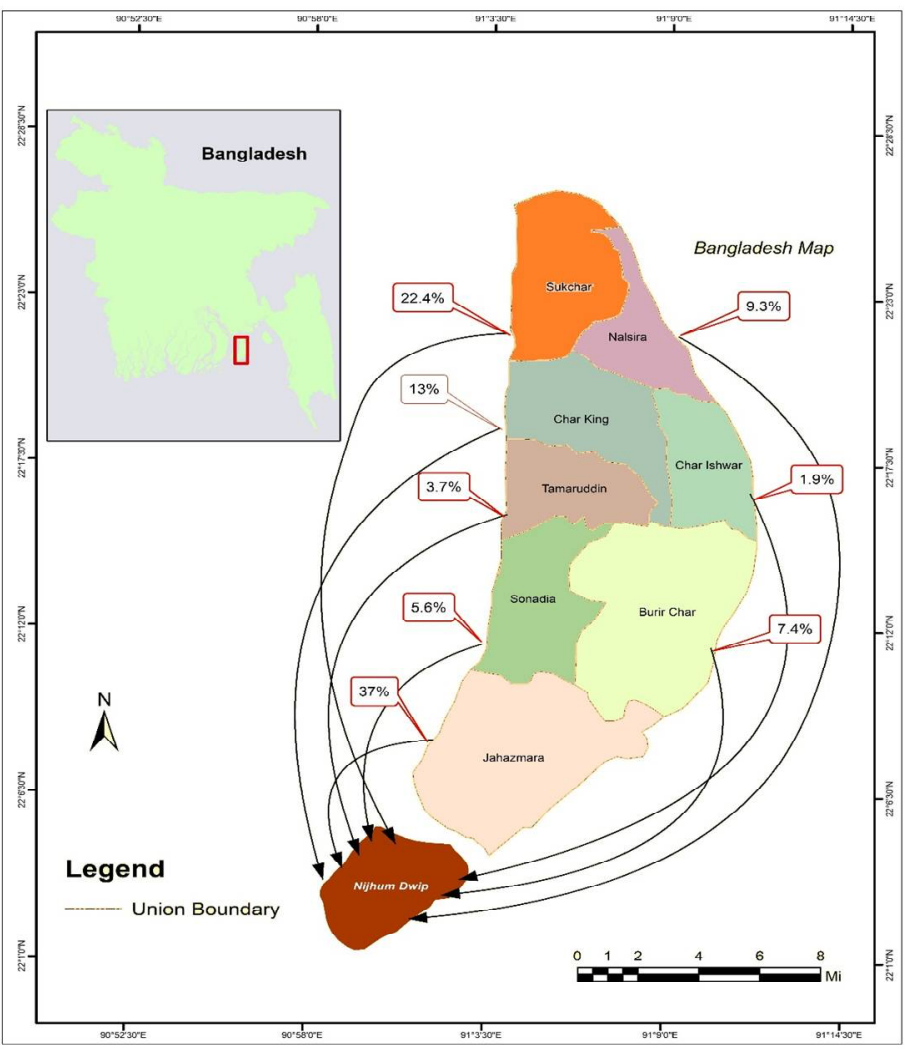

Source: Author's Field Survey, 2017

Map 1. Source of migration. 
Relative importance of livelihood capitals for adaptation of migrant community of Nijhum Dwip: The livelihood capitals (physical, natural, human, financial and Social) are taken from sustainable livelihood approach (SLA) provided by DFID (1999). The components of each capital comprise, Human capital (education, ecological knowledge, good health, mental strength, disaster management training), financial capital (cash savings, livestock, credit, wage/income, fisheries), natural capital (house steward, garden, wood/fruits, pond, agriculture), physical capital (house structure, sanitary latrine and tube well, electric line, road, cyclone shelter), social capital (social harmony, religious bond, neighbor co-operation, union parisad, co-operative association).

Human capitals: Among the criteria of human capital, it is found that education placed first with score 4.8 within 5 whereas the respondents acknowledged mental strength second with score 4.1 and followed by ecological knowledge, disaster management and good health with score 3.8, 3.7 and 3.1, respectively as the essential human capital for adaptation against climatic events in Nijhum Dwip.

Financial capitals: The Fig. 3 reveals that most important financial capital is cash savings (score 3.3) for coping in this island. The respondents recognized wage/income second with score 3.2 and credit and livestock (3.1) for each, fisheries (3) are also considered as important financial capital for coping with disasters in the area.

Natural capitals: It is evident from Fig. 3 that wood/fruit tree status first with score 3.9 within 5. To the respondents pond is the second natural capital (3.3) and followed by garden, house steward and agriculture stood next position with score 3.1, 2.9 and 2.8, respectively as the way of adjustment in the island.

Physical capitals: Maximum respondents of the study opined road (with score 4.3) is the most important physical capital. They stated cyclone shelter is second with score 4.2 and house structure (4.1), sanitary latrine (3.3) and tube-well (3.2), as the essential physical capitals to settle in Nijhum Dwip.

Social capitals: Regarding social capitals, most of the respondents mentioned neighbor cooperation is the most significant asset with score 4.3 within 5 . They mentioned cooperative operation (with score 3 ) is second important social capital and followed by social harmony, religious bond, union parisad with score 2.9, 2.4 and 2.3, respectively as the way of alteration for staying in the island.

Livelihood capitals: Among five livelihood capitals, it is found physical capital is the most significant livelihood capital with score 4.1 within 5 . The respondents admitted human capital second with 3.8 and followed by natural, financial, social capital scored 
3.3, 3.2 and 3.1 respectively were considered as important livelihood capitals for adapting with climatic hazards in Nijhum Dwip.

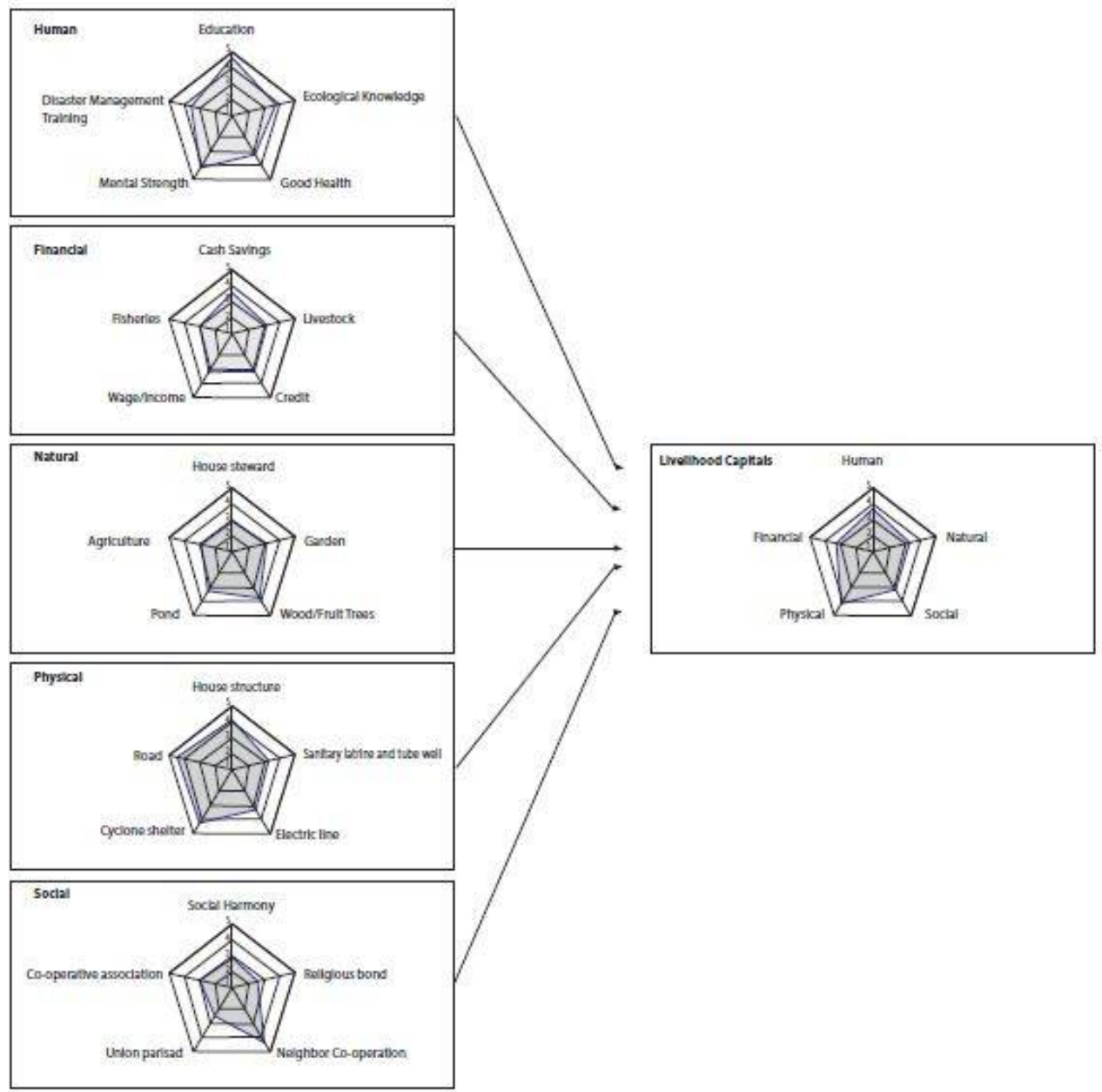

Source: Field survey, 2017.

Fig. 3. Relative importance of livelihood capitals for climate change adaptation of migrants community of Nijhum Dwip.

\section{Conclusion}

The study identified significant findings according to the objectives. As we know coastal areas are one of the most vulnerable places due to natural hazards so people need to migrate in search of alternative livelihoods. In most cases the destinations of such 
displaced people are the nearest urban area. However, the people of coastal region are not moving to better place for their economic insolvency rather they shift to new born island towards the sea. Before their migration most of the migrant families lost their homestead, crops, livestock and even job that is why they decided to migrate for different existing. River bank erosion was the prominent disaster to force them away from the place of origin. The respondents acknowledged the low price of land (86\%), no alternative place (82\%), easy to shift (72\%) as the major factors behind choosing Nijhum Dwip for settling there. The migrants were mainly from the neighboring area of Nijhum Dwip such as Jahajmara (37\%), Sukhchar (22.4\%), Nalchira (9.3\%) and so on.

Regarding relative importance of livelihood capitals the respondents admitted physical capital as the most important asset followed by human, natural, financial and social capital are also considered as significant livelihood capitals for adjusting in this island.

The findings of the study can contribute to add value to the existing knowledge on migrant community of Nijhum Dwip and their adaptation strategy. This study might be a significant document for policy makers, planners and government officials to take suitable solution either relocate the vulnerable people or retain them in their origin by enhancing their resilience.

\section{References}

Anwer, S. 2012. Climate Refugees in Bangladesh: Understanding the Migration Procss at the Local Level. Diakonisches Werk der EKD e.V, Germany.

Barman, S.D., S.C. Majumder, M.Z. Rahman and S. Sarker. 2012. Foundations of migration from the disaster consequences coastal area of Bangladesh. Developing Country Studies 2(4).

BBS. 2011. Population Census of Hatiya Upazila.Bangladesh Bureau of Statistics, Dhaka.

BBS. 2011. Population and Housing census 2011. Bangladesh Bureau of Statistics, Dhaka.

Brown, O. 2008. Migration and Climate Change. International Organization for Migration. Geneva. Retrive From June 12, 2017, http://www.iom.int

Campbell J. and O. Warrick. 2014. Climate Change and Migration Issuses in the Pacific. United states: United Nations Economic and Social Commission for Asia and the Pacific.

DFID. 1999. Sustainable Livelihoods Guidance Sheets. Department for International Development.

IOM. 2008. World Migration Report 2008: Managing Labour Mobility in the Evolving Global Economy. IOM ONLINE BOOKSTORE, Geneva. $562 \mathrm{pp}$.

IPCC. 2014. Climate change 2014. Impacts, Adaptation and Vulnerability. Summary for Policymakers.Working Group II Contribution to the Fifth Assessment Report of the Intergovernmental Panel on Climate Change. Cambridge University Press, Cambridge, United Kingdom and New York, NY, USA. pp.1-32.

Hossain, K.T., I.A. Tanim and M. Saluddin. 2016. Change Detection of Forest Cover : A study Nijhum Dwip Natioal, Park,Hatiya, Noakhali. Journal of Life and Earth Sciences, Jagannath University 2(2): 54-90. 
Hossain, M.S., S. Thompson, M.R.U. Nabi and M.M. Kibria. 2013. Climate change resilience assessment using livelihood assets of coastal fishing community in Nijhum Dwip, Banglades. Pertanika Journal of Science \& Tecnology 21(2): 397-422.

Pascoe, S. 2015. Sailing the Waves on Our Own: Climate Change Migration, Self-Determination and the Carteret Islands. QUT Law Review 15(2): 72-85. Retrived From June 15,2017 doi: 10.5204/qutlr.v15i2.610

Rayhan, I. and U. Grote. 2007. Coping with floods: Does rural-urban migration play any role for survival in rural Bangladesh?. Journal of Identity and Migration Studies 1(2): 82-98.

Saha, P.K., M. Bodiuzzaman, M.N. Uddin, M.N. Hossain and A.S. Shanta. 2014. A Study on the management strategies of protected area in Bangladesh for biodiversity conservation on Nijhum Dwip, Noakhali, Bangladesh. International Journal of Innovative Research and Development 3(7): 140-148.

Siddiqui, M.R. 2014. Patterns and factors of out-migration in the Meghna estuarine islands of Bangladesh. Malaysian Journal of Society and Space 10(1): 11-24.

Stojanov, R., I. Kelman, AKM. Ullah, D. Procház, Duží, D. Procházka and K.K. Blah utová. 2016. Local expert perceptions of migration as a climate change adaptation in Bangladesh. Sustainability 8(12): 1223 Retrieved From June 12, 2017 doi:10.3390/su8121223

Tanim, S.H. and D.C. Roy. 2013. Climate Induced Vulnerability and Migration of the People from Islands of Bangladesh: A Case Study on Coastal Erosion of Kutubdia Island. Planned Decentralization : Aspired Development. World Town Planning Day 2013.

Torresan, S., A. Critto., M.D. Valle, N. Harvey and A. Marcomini. 2008. Assessing coastal vulnerablility to climate change: Comparing segmentation at global and regional scales. Sustainability science. Copernicus Publications on behalf of the European Geosciences Union. 3(1): 45-65. Retrived From August 15, 2017, http://www.nat-hazards-earth-systsci.net/12/2347/2012/

(Revised copy received on 8.7.2018) 